Jolanta Chomko

DOI $10.15290 / \mathrm{sw} .2020 .20 .12$

Uniwersytet w Białymstoku

Wydział Filologiczny

Kolegium Językoznawstwa

tel.: +48857457450

e-mail: j.chomko@uwb.edu.pl

ORCID ID: https://orcid.org/0000-0003-0289-7221

\title{
Nazwy barw w opisach przyrody nieożywionej (na materiale opowiadań Aleksandra Grina)
}

Słowa kluczowe: Grin, idiolekt pisarza, semantyka barw, przyroda nieożywiona

\section{Wstęp}

Nazwy barw są integralnym elementem opisu świata, ponieważ kolor jest nieodłączną cechą wszystkich obiektów materialnych. Właściwości kolorystyczne mogą przysługiwać danemu obiektowi trwale lub ulegać zmianie, np.: jaśnieć, ciemnieć, przekształcać się w inny typ, itp. Zależy to od rodzaju obiektu i ujęcia tego faktu przez nadawcę [Ampel-Rudolf 1994, s. 8]. Definicje koloru sformułowane w opisowych słownikach języka polskiego są bardzo podobne do siebie, podkreślają, że jest to cecha przedmiotu odbierana wzrokowo i zależna od światła: 'postrzegana wzrokowo właściwość przedmiotu, zależna od stopnia pochłaniania, rozpraszania lub przepuszczania promieni świetlnych'1, 'postrzegana wzrokowo właściwość przedmiotów związana z ich oświetleniem lub odbijaniem przez nie światła'2, 'odbierana wzrokowo cecha danej rzeczy, zależna nie od jej kształtu, ale od tego jak odbija ona światło' [Inny słownik..., 645].

\footnotetext{
1 https://sjp.pwn.pl/szukaj/kolor.html [20.01.2020].

2 https://www.wsjp.pl/index.php?id_hasla $=511 \& i d \_z n a c z e n i a=1397136 \& l=13 \& i n d=0$ [20.01.2020].
} 
Analiza nazw barw dostarcza cennych informacji o modelach percepcji, asocjacji i interpretacji świata przedstawionych w utworze literackim. Jak zauważa I.G. Czernienek, „колоративы в художественном дискурсе, несмотря на определенную ассоциативную заданность культурной традицией, многозначны и порой амбивалентны. Это означает, что эмоционально-эстетическое восприятие «цветовой» информации в тексте определяется тем, с каким предметным содержанием она связана, какие эмоции вызывает у читателя" [Черненок 2008, 179-183].

Niniejsza praca stanowi próbę rekonstrukcji fragmentu kolorystycznego obrazu świata wybitnego rosyjskiego pisarza Aleksandra Grina, którego nazywa się malarzem, przedstawiającym świat wielobarwny, tworzącym swój własny „mówiący” i znaczący świat, podporządkowany swoim określonym zasadom twórczości [Мельникова 2009, 64]. Przedmiotem analizy są nazwy barw wykorzystane przez autora do opisu świata przyrody nieożywionej ${ }^{3}$. Materiał źródłowy stanowią opowiadania tego pisarza ${ }^{4}$.

\section{Konceptualizacja wody}

Jednym z elementów świata przyrody nieożywionej są wody powierzchniowe. W opowiadaniach A. Grina pojawiają się takie rozlewiska wodne, jak ocean, morze, jezioro, rzeka i potok. W kreowaniu ich obrazów uczestniczą nazwy kolorów wchodzące w skład kilku pól barw: pola barwy niebieskiej, zielonej, białej, czarnej i szarej.

$\mathrm{W}$ analizowanych utworach najczęściej występującym zbiornikiem wodnym jest morze, którego kolor zależy od pory dnia i nasilenia światła w cyklu dobowym. Największą frekwencją w jego opisie cieszą się nazwy barw z pola błękitu. Jest to zarówno podstawowa nazwa barwy, синиŭ, która odnosi się do koloru morza w opowiadaniu Kapitan Duc: После этих воспоминаний Дюк перешел к обиженной «ветряной мельниче», «Марианне». Пустая, высоко подняв грузовую ватерлинию над синей водой, покачивается она на рейде так тяжко, так жалостно, как живое, взды

3 Przyroda nieożywiona to wszystkie czynniki abiotyczne, kształtujące miejsce życia organizmów, które przystosowują się do nich. Składają się na nią między innymi takie czynniki, jak: wody powierzchniowe i podziemne, ukształtowanie powierzchni terenu, podłoże skalne, panujący na danym obszarze klimat, a także chemiczny skład wód i atmosfery.

4 Materiał do analizy został wyekscerpowany z: A.С. Грин, 1994, Собрание сочинений в пяти томах, Москва oraz przekładów opowiadań na język polski. 
хающее всей грудью существо (Utw. 2, 360) / Po tych wspomnieniach Duc przeszedt do rozmyślań nad pokrzywdzonym „wiatrakiem” „Marianna”. Pusta, z wysoko uniesiona nad sina woda waterlinia obciażenia chwieje sie na redzie tak ciężko, tak żałośnie, jak żywa, wzdychajaca cała piersia istota (PO, 64), jak i derywowany od niej rzeczownik синева w opowiadaniu Fandango: За уступами крыши, разбросанньх ниже этого дома, до судовых мачт и моря, блестящего чеканной синевой волн, стучали колеса, пели петухи, нестройно голосили прохожие (Utw. 3, 543) / Za załomami dachów, rozrzuconych poniżej tego domu, stukały koła, piaty koguty, rozlegaty się beztadne krzyki przechodniów (SzŻ, 353), jak również leksem голубой, który został wykorzystany w utworze Cieśnina Burz: Плечи опухли, ньли; сознание бродило в тумане, словно невидимая рука все время пьталась заслонить от его взгляда тихий прибой, голубой проход бухты, где стоял «Фитиль на порохе», и яркое, живое лицо прошльх суток (Utw. 1, 441) / Spuchnięte ramiona doskwieraty mu, świadomość bładziła we mgle, jak gdyby niewidzialna ręka przez cały czas usitowała zastonić przed jego wzrokiem tagodne fale przyboju, błękitne pasmo zatoki, gdzie stat "Lont na beczce prochu”, i barwne, żywe oblicze minionych dni (SD, 154), Он осмотрелся; голубая тишина бухты несколько ободрила его (Utw. 1, 444) / Obejrzat się; btękitna cisza zatoki dodała mu nieco otuchy (SD, 158), w opowiadaniu Komendant portu: Никаких корыстных челей он не преследовал, его влекло к морякам и кораблям с детства, с тех пор как еще на руках матери он потянулся ручонками к спускающемуся по голубой стене моря видению nарусов (Utw. 3, 613) / Nie miał na celu żadnych korzyści materialnych, po prostu ciagnęto go do marynarzy i statków od dziecinstwa, od czasu, kiedy jeszcze $w$ ramionach matki wyciagat raczki $w$ strone sunacych po btękitnej tafli morza bialych żagli (SzŻ, 135) oraz w tekście Fandango: Проuaü, ученый мир, и да здравствует голубое море! (Utw. 3, 525) / Żegnaj, uczony świecie, i niechaj żyje btękitne morze! (Sż̇, 319). W opowiadaniu Cieśnina Burz do opisu morza została użyta niepodstawowa nazwa barwy, wyrażona rzeczownikiem лазурь: Дремлющий, одинокий корабль стройно чернел в лазури (Utw. 1, 445) / Drzemiacy samotny statek czerniat wyniośle na tle btękitu (SD, 161).

Pole zieleni w opisie morza jest reprezentowane przez dwa przymiotniki: зеленый і зеленоватый. Pierwszy z nich został przywołany $\mathrm{w}$ takich opowiadaniach, jak: Sześć zapatek: Вечерело; шторм снизил давление, но волны еще не вернули тот свой живописньй вид, какой настраивает нас покровительственно в отношении $\kappa$ морской стихии, когда, лежа на берегу, смотрим в их зеленую глубину (Utw. 3, 410) / Mia- 
to się ku wieczorowi; napór sztormu byt stabszy, ale fale nie nabrały na powrót tej malowniczości, jaka nastraja nas protekcjonalnie wobec żywiołu morza, gdy leżac na brzegu patrzymy w ich zielona głab (ON, 311), Fandango: Я отступил, так были хороши эти иветь дна морского среди складок шелка и полотна, - они хранили блеск подводного луча, проникающего в зеленую воду (Utw. 3, 519) / Az sie cofnatem, takie byty piękne kwiaty dna morskiego - wśród fałd jedwabiu i płótna zachowały blask podwodnego promienia przenikajacego zieleń wody (SzŻ, 309) i Szary samochód: Среди зеленого серебристого моря холмов вилось несколько троп; одна из них была круче, и я скатился по ней к лежащему ниже uocce (Utw. 3, 449) / Wśród zielonego, srebrzystego morza wzgórz wiło się kilka ścieżek, jedna z nich była bardziej stroma i stoczyłem sie z niej na leżaca niżej szosę (Szcz., 356). Leksem зеленоватый występuje w opisie morza w Żyсіи Gпога: Зеленоватые отсветы волн, бегущих за кругльмм стеклом иллюминатора, ползли вверх, колебались у потолка и снова, повинуясь размахам судна, бесшумно неслись вниз (Utw. 1, 615) / Zielonkawe zwaty fal, toczacych się za okragta szyba iluminatora, wspinaty się w góre, chwiaty sie u sufitu i poddajac sie pędowi statku, znowu cicho opadały $w$ dót (SD, 221).

Nieoświetlona promieniami słońca morska woda nabiera czarnego koloru, co zostało przedstawione w kilku opowiadaniach. Należą do nich: utwór Sześć zapałek: Меж этими страшными и крутыми массами черного ивета стеклянно блестел выем, в тот же миг, как вы заметили его, взлетаюший выпукло и черно на высоту трехэтажного дома (Utw. 3, 410) / Pomiędzy tymi strasznymi pionowymi masami wód o czarnej barwie szkliście potyskiwało wgtębienie, które w tej samej chwili, kiedy sie je dostrzegło, wzlatywało, wzdymało sie i czerniało na wyskości dwupiętrowego domu (ON, 311), opowiadanie Kolonia Lanfier: Ночь спрятала его корпус; разночветнье огни мачт и светящиеся кружочки иллюминаторов двоились в черном зеркале моря; безветренная густая мгла пахла смолой, гниюшими водорослями и солью (Utw. 1, 285) / Noc ukryła jego sylwetkę; różnokolorowe ognie masztów i świecace się krązki iluminatorów dwoity się w czarnym lustrze wody, bezwietrzna, gęsta mgła pachniała smoła, gnijacymi wodorostami i sola (Szcz., 5), tekst Spadek ро Pik-Miku: Я видел черную, стремительно убегаюшую воду, красные фонарики, военный корабль, кусок болота, освещенный рефлектором (Utw. 2, 441) / Widziałem czarna, szybko uciekajaca wode, czerwone latarki, okręt wojenny, część błota oświetlona reflektorem (Szcz., 131) oraz Kapitan Duс: У мола, поскрипьвая, толкались на зыби черные шлюпкu, и черная вода под ними сверкала искрами (Utw. 2, 359) / Przy 
molo poskrzypujac tracały się na drobnej fali czarne tódki, a czarna woda pod nimi blyskata skrami (PO, 62).

W opowiadaniu Cieśnina Burz opisy morza współtworzą także nazwy barw z pola bieli. Są to przymiotnik бельй: Волнение усиливалось; отлогие темные валь с ровным, воздушныл гулом катились в пространство, белое кружево вспьхивало на их верхушках и гасло в растущей тьме (Utw. 1, 438) / Fala była coraz silniejsza; pochyłe ciemne zwały wód z równomiernie wypelniajacym powietrze toskotem toczyly się gdzieś w przestrzeń; na ich szczytach wykwitała biała koronka i ginęla w gęstniejacym mroku (SD, 150) i leksem серебристьй ${ }^{5}$ Пролив казался спокойными ангельскими глазами изменившей женьг; он стих, замер и просветлел, поглаживая серебристыми языками желтый пеcoк / Cieśnina przypominała niewinne, anielskie oczy wiarołomnej żony, wody przycichty, uspokoity się i przejaśniały liżac srebrzystymi językami zótty piasek (SD, 155)

W opowiadaniach A. Grina dość często pojawiają się opisy rzek. Podobnie, jak w przypadku morza, dominującym w nich kolorem są odcienie błękitu. W utworze Kolonia Lanfier do językowej kreacji rzeki autor używa przymiotnika голубой: - Там! - взмахивая рукой и, видно, приходя в себя, крикнул Бекеко. - Маленькая голубая река (Utw. 1, 316) / - Tam! - krzykną Bekeko wymachujac ręka $i$ zapewne odzyskujac świadomość. - Maleńka btękitna rzeka (Szcz., 54), Север, маленькая голубая река (Utw. 1, 317) / Pólnoc, maleńka btękitna rzeka (Szcz., 54), Маленькая голубая река текла перед его глазами (Utw. 1, 317) / Maleńka błękitna rzeka ptynęta przed nim (Szcz., 55), Через нолчаса он увидел воду. Конечно, это была та самая маленькая голубая река, узкий ручей с небом на дне и блеском песчаньх отмелей, чистых, как серый фаянс. Издали она казалась голубой лентой в зеленой косе нимфь (Utw. 1, 318) / Po półgodzinie zobaczył wodę. Oczywiście była to ta sama maleńka, błękitna rzeka, waski strumyk z niebem na dnie i blaskiem piaszczystych mielizn tak czystych jak szary fajans. $Z$ daleka podobna była do btękitnej wstegi z zielonym warkoczem nimfy (Szcz., 56), Горн, с трудом передвигая ноги в сырой гуще чепкой травы, выбрался к голубой ленте и остановился, вдыхая сладкий прельй запах водорослей

5 Barwa srebrna jest niepodstawową nazwą przyporządkowaną bieli. Kolorystyczne określenie srebrny posiada „swoisty odcień metalicznego połysku, nie gubiąc jednocześnie związku z bielą" . Związek ten można zauważyć zarówno w etymologicznym pokrewieństwie nazw 'bieli' i 'srebra' $\mathrm{w}$ wielu językach indoeuropejskich, jak i w perceptualnym podobieństwie poświadczonym materiałem leksykalnym i faktami pozajęzykowymi [Tokarski 2004, 70-71]. „Srebrny to kolor fizycznie bliski białemu” [tamże, 73]. 
(Utw. 1, 318) / Gorn, z wysitkiem poruszajac nogami w mokrej gęstwinie chwytliwych traw, dotart do błękitnej wstegi i zatrzymat się wdychając słodka, stęchta woń wodorostów (Szcz., 56), Ему пришло в голову, что всем известно о маленькой голубой реке (Utw. 1, 322) / Oprócz tego przyszło mu do głowy, że wszyscy wiedza o maleńkiej błękitnej rzece (Szcz., 63), Маленькая голубая река никогда не видала их (Utw. 1, 324) / Maleńka, btękitna rzeka nigdy ich nie widziała (Szcz., 66), Маленькая голубая река невинно скользила перед глазами (Utw. 1, 334) / Maleńka, btękitna rzeka niewinnie ślizgała się przed oczami (Szcz., 81). Ten sam odcień błękitu występuje również w opowiadaniu Lina: Белье балконы, желтые плить тротуара и голубая река с перекинутыми вдали отчетливыми мостами казались мне, в торжественной строгости моего отношения ко всему этому блеску жизни, робкой лестью побежденньх неукротимому победителю (Utw. 3, 201) / Białe balkony, żótte płyty chodnika $i$ btękitna rzeka z przerzuconymi, w dali wyraźnie rysujacymi sie mostami wydawaly mi sie z pompatycznej surowości mojego stosunku do wszystkich blasków życia nieśmiałym pochlebstwem pokonanych wobec nieposkromionego zwycięzcy (Szcz., 180).

W kontekście opisu rzek pojawia się jeszcze jeden leksem z pola błękitu - синий, który zostaje przywołany dwóch opowiadaniach - Sprzedawсу szсzе̨ścia: Скоро пришел он к синей узкой реке, блестевшей солнчем под безоблачным небом (Utw. 2, 158) / Wkrótce staną nad sina waska rzeka, polyskujaca w stońcu pod bezchmurnym niebem (SD, 182), Безмолвная река развертывалась перед ним пьиной, синей аллеей, извилисто проникая в знойную тесноту дремлющих лесных берегов (Utw. 2, 159) / Przed nim rozpościerała sie milczaca rzeka, niczym przepyszna modra aleja, i kręto ześlizgiwała się w skwarna ciasnote drzemiacych leśnych brzegów (SD, 183) oraz w utworze Sto wiorst brzegiem rzeki: Coлнечный шар плавился над синей рекой, играя с пространством легкими, дрожащими блестками, рассыпанньми везде, куда направлялся взгляд (Utw. 2, 533) / Kula słońca topniała nad błękitna rzeka mieniac sie w przestrzeni lekkimi, drżacymi cekinami, rozsypanymi wszędzie, gdzie siegat wzrok (SzŻ, 166).

$\mathrm{W}$ niewielkim stopniu $\mathrm{w}$ opisie rzek pojawia się barwa zielona, została ona przywołana tylko w utworze Sprzedawca szczęścia: Далеe, как высыпанная из корзин зелень, купались в зеленеющей отражениями воде гирлянды ветвей, образуя тенистье боковье коридоры (Utw. 2, 159) / Dalej, jak by kto zielen wysypat z kosza - to kapaty sie w wodzie, co zielenita sie ich odbiciami, girlandy gałezi tworzacych cieniste boczne korytarze (SD, 183). 
Jednokrotnie poświadczony w językowym obrazie rzeki jest również przymiotnik черньй, występujący w Napowietrznych rusatkach: Здесь именно потому, что он считал предосудительным думать, - несколько сказок рассмеялось ему в лицо плеском маленьких рук, выжимаюших зеленье косы над утонувшим в черной воде месячным медным серпом (Utw. 3, 292) / A to wtaśnie dlatego, że uważat myślenie za karygodne - kilka bajek roześmiało mu sie $w$ twarz pluskiem maleńkich rak wykrecajacych zielone warkocze nad utopionym w czarnej wodzie miedzianym sierpem księżyca (Szcz., 246).

Paleta barw opisujących jeziora nie różni się zbytnio od kolorów wykorzystanych do opisu pozostałych zbiorników wodnych. W ich językowej kreacji obecne są przede wszystkim barwy skupione wokół centrum semantycznego, jakim jest błękit i wyrażone przy pomocy leksemu голубой, tak jak w opowiadaniu Kolonia Lanfier: B просветах, наполненньх темнозеленой густой тенью и золотыми пятнами солниа, сверкали крошечные голубые кусочки озера (Utw. 1, 289) / W prześwitach wypeknionych ciemnozielonym, zagęszczonym cieniem i złotymi plamami słońca pobłyskiwały maleńkie, błękitne kawałeczki jeziora (Szcz., 12), Прямо перед ним узкой, затуманенной полосой тянулся противоположньй берег; голубая, стального оттенка поверхность озера дымилась, как бы закутанная тончайшим газом (Utw. 1, 290) / Naprzeciw, waskim, zamglonym pasmem ciagnat sie przeciwlegty brzeg; btękitna, o stalowym odcieniu powierzchnia jeziora dymita sie, jak gdyby była owinięta delikatna gaza (Szcz., 12), Озеро дымилось. Колеблющиеся испарения устилали поверхность, обнажая у берегов светлье, голубье лужицы заснувшей воды (Utw. 1, 301) / Jezioro parowało. Kotyszace się opary zaścielaty powierzchnie, obnażaty przy brzegach jasne, błękitne płachty sennej wody (Szcz., 29) lub przymiotnika синий - w utworze Piekło odzyskane: Затем я продолжал разговор, спрашивая себя, не последний ли раз вижу я это прекрасное, нежно нахмуренное лищо, эти реснищь, длиннье, как вечерние тени на воде синих озер, и рот, ульбающийся проникновенно, и нервную, живую белизну рук (Utw. 2, 402) / Potem rozmawiałem z nia dalej, zapytujac sam siebie, czy nie po raz ostatni widze te piękna, czule zasmucona twarz, te rzęsy, dlugie jak cienie wieczoru w wodzie granatowych jezior, i usta, rzewnie uśmiechnięte, i nerwowa, żywa białość dtoni (PO, 8).

W kształtowaniu obrazu jeziora uczestniczy równeż jednokrotnie poświadczony tylko w tekście Kolonia Lanfier przymiotnik стальной ${ }^{6}$, który

6 Стальной 'имеющий цвет стали; серебристо-серый' [Кузнецов 2000, 1259]. 
„może kojarzyć się z chłodem, zagrożeniem, wrogością wobec człowieka" [Tokarski 2004, 63]: Прямо перед ним узкой, затуманенной полосой тянулся противоположный берег; голубая, стального оттенка поверхность озера дымилась, как бы закутанная тончайшим газом (Utw. 1, 290) / Naprzeciw, waskim, zamglonym pasmem ciagną sie przeciwległy brzeg; btękitna, o stalowym odcieniu powierzchnia jeziora dymita się, jak gdyby była owinięta delikatna gaza (Szcz., 12).

Do opisu oceanu Grin wykorzystał w opowiadaniach kolory z palety błękitu, zieleni, bieli i czerni. Stosunkowo często występują barwy będące odcieniami błękitu, do których należą: синий - w opowiadaniu: Życie Gnora: Полдень горел всей силой огненных легких юга; чудесная простота океана, синий блеск его окружал яхту (Utw. 1, 617) / Petnia dnia oddychała cała moca ognistych pluc Poludnia; cudowna prostota oceanu, jego błękitnawy blask otaczat jacht; nagie opalone plecy marynarzy zginaty sie pod opuszczonymi żaglami, przypominajacymi rozwieszona bielizne giganta (SD, 225) i utworze Kolonia Lanfier: На западе, облегая изрытую оврагами и холмами равнину, тянулась синяя, сверкающая бельми искрами гладь далекого океана (Utw. 1, 292) / Na zachodzie rozciagała się, otaczajac poryta parowami i wzgórzami równinę, błękitna, mieniaca się białymi iskrami, gładź dalekiego oceanu (Szcz., 16), jak również голубой - w tekście Zatruta wуspa: Солнечные лучи, дробясь над аркой, делали воздух подобием пылающего костра или золотой завеcbl, сквозь которую просвечивали голубыли тенями извивы берега. Берег пестрел иветами (Utw. 2, 577) / Rozproszone nad arka promienie słoneczne czynity z powietrza coś na kształt płonacego ogniska lub złocistej zasłony, przez która przeświecały lazurowymi cieniami zarysy ukwieconego brzegu (ON, 134).

Jednokrotnie poświadczony w językowej kreacji oceanu jest przymiotnik зеленоватый, który pojawia się w opisie tego zbiornika w opowiadaniu Życie Gnora: На краю неба, в беспрерывно мигающем свете небесных трещин, неудержимо влеклись к далеким облакам пенистые зеленоватые вальь (Utw. 1, 621) / Na krańcach nieba, w nieustannym migotliwym świetle ognistych zygzaków, niepowstrzymanie pędzity ku dalekim chmurom zielonkawe spienione batwany (SD, 230).

Do charakterystyki oceanu wykorzystano również barwę białą, która w tekście Kolonia Lanfier odzwierciedla odbijające się w wodzie światło: На западе, облегая изрытую оврагами и холмами равнину, тянулась синяя, сверкающая бельми искрами гладь далекого океана (Utw. 1, 292) / Na zachodzie rozciagała sie, otaczajac poryta parowami i wzgórzami równine, błękitna, mieniaca sie biatymi iskrami, gładź dale- 
kiego oceanu (Szcz., 16). W opowiadaniu Życie Gnora, natomiast, opisuje ona fale przypływu: Голье обожженные спинь матросов гнулись над опущенными парусами, напоминавшими разбросанное белье гиганта; справа, отрезанная белой нитью прибоя, вьсилась скалистая впадина берега (Utw. 1,617) / Nagie opalone plecy marynarzy zginaty sie pod opuszczonymi żaglami, przypominajacymi rozwieszona bielizne giganta; na prawo, odcięta biata nicia przyboju, wznosita sie skalista zapadlina brzegu (SD, 225).

Sporadycznie, tylko w opowiadaniu Życie Gnora, do opisu wody oceanicznej autor wykorzystuje barwę czarną, która określa zmieniający się pod wpływem braku światła zbiornik wodny: Голубье молнии полосовали пространство; меня вместе с плотом швыряло то вверх - $\kappa$ тучам, то вниз - в жидкие черные ямь (Utw. 1, 621) / Btękitnawe błyskawice rozdzieraty przestwór. Tratwe wraz ze mna ciskało to w góre, ku chmurom, to $w$ dót, w czarne wodne czeluście (SD, 230).

W opisie potoku w utworze Zatruta wyspa Grin wykorzystał kolory z pola błękitu i bieli. W obu przypadkach nazwy barw zostały wyrażone derywatami rzeczownikowymi - белизна: Очень прост и величествен был свадебный обряд. Мы стояли на берегу потока, сверкавшего синевой и белизной в изломах гранита, сомкнувшегося впереди нас, через поток, прихотливой тенисто-краснеющей аркой (Utw. 2, 577) / Obrzęd ślubny byt nader prosty i wspaniały zarazem. Staliśmy na brzegu potoku lśniacego błękitem i biela w załomach granitu, który przed nami, na drugim brzegu, tworzył wymyślna cienista arke (ON, 134) і синева: Очень прост и величествен был свадебньй обряд. Мы стояли на берегу потока, сверкавшего синевой и белизной в изломах гранита, сомкнувшегося впереди нас, через поток, прихотливой тенисто-краснеющей аркой (Utw. 2, 577) / Obrzęd ślubny byt nader prosty $i$ wspaniaty zarazem. Staliśmy na brzegu potoku lśniacego błękitem i biela w załomach granitu, który przed nami, na drugim brzegu, tworzyt wymyślna cienista arkę (ON, 134).

\section{Konceptualizacja powierzchni terenu i podłoża skalnego}

Drugim istotnym polem semantycznym, tworzacym świat przyrody nieożywionej, jest powierzchnia kuli ziemskiej - jej ukształtowanie i podłoże skalne. Językowy obraz tych elementów budują kolory należące do pola barwy niebieskiej, białej, czarnej, szarej, żółtej, zielonej oraz czerwonej.

Ziemia, jako część krajobrazu przedstawionego na obrazie, pojawia się w opowiadaniu Fandango, gdzie autor opisał ją przy pomocy przy- 
miotnika сизыйт: Это был тоже пейзаж, составленный из двух горизонтальных полос; серой и сизой, с зеленьли по ней кустиками

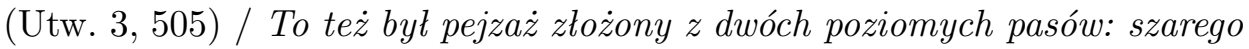
i szaroniebieskiego, z zielonymi krzaczkami (Sż̀, 283).

Opisy poszczególnych fragmentów ukształtowania terenu pojawiają się w analizowanych tekstach dość rzadko. Należą do nich między innymi obrazy wzniesień. W opowiadaniu Piekło odzyskane do budowy obrazu gór Grin wykorzystał rzeczownik синева: Утро явилось в тот день отменно красивыл; стянув к небу от многоцветных осенних лесов все силь блеска и ликования, оно соединило их вдали, над воздушной синевой гор, в пламенном ядре солниа, драгоценным аграфом, скрепляюшим одежды земли (Utw. 2, 403) / Poranek tego dnia wypadt przedziwnie piękny. Zebrawszy na niebo z wielobarwnych lasów wszystkie moce blasku i tryumfu, $w$ dali, nad przejrzystym błękitem gór, złaczył je w płomiennej kuli słońca, jak gdyby drogocenna brosza, przytrzymujaca suknie ziemi (PO, 9).

W utworze Szary samochód w opisie wzniesień pojawiają się leksemy серый і серебристый: Наконеи он выкатился с холма издали серым наростом среди живописньх картин дороги и начал валиться по ее склону на зрителя, увеличиваясь и приближаясь к натуральной величине (Utw. 3, 421) / Wreszcie wyjechat na wzgórze, niby szara narośl pośród malowniczych obrazów drogi, i zaczą po jego skłonie staczać się na widza, rosnąc i zbliżając się do wielkości naturalnej (Szcz., 312), Среди зеленого серебристого моря холмов вилось несколько троп; одна из них была круче, и я скатился по ней к лежащему ниже шоссе (Utw. 3, 449) / Wśród zielonego, srebrzystego morza wzgórz wiło się kilka ścieżek, jedna $z$ nich była bardziej stroma $i$ stoczyłem się z niej na leżaca niżej szose (Szcz., 356).

Sporadycznie autor opowiadań przywołuje kolor w opisie innych form ukształtowania terenu. Należą do nich równiny, które w Losie chwyconym za rogi zostały określone barwą białą z powodu leżącego na nich śniegu: Белье равнинь, в голубом свете луны, под черным небом - холодно, по-зимнему, звездным, молчащим небом; неотстающая черная тень лошади, прыгающая под ее брюхом, и ясная кривая горизонта давали что-то от вечности (Utw. 2, 270) / Białe równiny w błękitnym świetle księżyca, w górze czarne niebo - chłodno, zimowo rozgwieżḋone i milczace niebo, nieodstępny czarny cień konia, skaczacy pod jego brzuchem i wyraźna pólkolista linia horyzontu nasuwały myśl o wieczności (SD, 163), oraz czarne urwiska w utworze Sprzedawca szczęścia: Обрыьы, черные, как груды

7 Сизый 'темно-серый с синеватым отливом' [Кузнецов 2000, 1184]. 
угля, с выползающими к воде розовыми корнями, сменялись колоннами бесконечно уходящих в полумрак зарослей стволов (Utw. 2, 159) / Na przemian sunęty urwiska, czarne jak bryty wegla, z petznacymi ku wodzie różowymi korzeniami, i kolumny pni uchodzacych w bezkresny pótmrok zarośli (SD, 183).

Barwa czarna posłużyła również do językowej kreacji obrazu brzegu w opowiadaniu Sto wiorst brzegiem rzeki: Стемнело. Красное веко солнца скрыьвалось за черным берегом (Utw. 2, 538) / Zmierzchto. Czerwona powieka słońca zapadała za czarny brzeg (Sż̇, 177).

W opowiadaniach A. Grina stosunkowo często pojawiają się opisy skał i minerałów tworzących skorupę ziemską i glebę. Barwa biała uczestniczy kształtowaniu obrazów skał kredowych, które zostały opisane w dwóch utworach - Ciеśnina Burz: Рифы остались сзади, впереди лежал океан, слева - меловые утесы, похожие на кучки белых овец, скрывали бухту (Utw. 1, 442) / Rafy zostaty $w$ tyle, przed nim leżat ocean, na lewo - skaty kredowe podobne do trzód biatych owiec przystaniaty zatoke (SD, 155) oraz Piekto odzyskane: Oт бельх камней в желтой пьли дороги лежали темно-синие тени, пальй лист всех оттенков (Utw. 2, 403) / Od biatych kamieni na żótty pył drogi kładty sie granatowe cienie, opadłe liście wszystkich barw (PO, 9).

Do opisu skał posłużyły również barwy pola żółcieni - wyrażone czasownikiem желтеть, odnoszącym się do skał kwarcowych, przedstawionych w Kolonii Lanfier: Обломки квариа, следьи бьвиих землетрясений желтели отраженным светом зари, короткое бормотание какаду звучало сердитьм удовлетворением и строптивостью (Utw. 1, 318) / Odtamki kwarcu - ślady minionych trzęsień ziemi - żótcity się odbitym świattem zorzy, krótkie mamrotanie kakadu dźwięczało jak watpliwe zadowolenie i przekora (Szcz., 56) oraz przymiotnikiem желmbiŭ, określającym głazy na dnie strumienia w Kapitanie Charbelu, które pod wpływem otaczających je wodorostów przybierały również barwę zieloną: Желтыле, как золото, и зеленые, в водорослях, крупнье камни загромождали дно (Utw. 2, 451) / Wielkie kamienie, żótte jak złoto, a wśród wodorostów zielone, zaścielaty dno (SD, 6).

Jednym z rodzajów skał jest piasek, należący do skał osadowych luźnych, który w analizowanych tekstach pojawia się dość często. W kształtowaniu jego obrazów uczestniczy kilka barw, między innymi barwa biała, wyrażona przymiotnikiem бельй - w opowiadaniu Gadatliwy skrzat: Желтьии и лиловатый и темно-зеленьй свет отражень на белом песке. Холодная вода в такой день лучше всего (Utw. 3, 257) / Na biatym piasku odbija sie źótte, kredowe i ciemnozielone światto (PO, 160), w utwo- 
rze Kapitan Duc: Бесформенные длинные тени скрещивались на белом necke (Utw. 2, 355) / Bezksztaltne, długie cienie przecinały się na biatym piasku (PO, 57) oraz w tekście Kolonia Lanfier: На востоке, за озером, вилась белая нитка дороги, ведущей в город, по краям ее кое-где торчали деревья, казавшиеся издали крошечными, как побеги салата (Utw. 1, 292) / Na wschodzie za jeziorem ciagnęła się biała nitka drogi prowadzacej do miasta, na jej bokach gdzieniegdzie sterczaty drzewa, które z daleka wydawaty się maleńkie jak pędy sałaty (Szcz., 16).

Kolejną barwą współtworzącą obraz piasku jest barwa żółta, wyrażona leksemem желтьй w dwóch opowiadaniach - w Cieśninie Burz: Пролив казался спокойными ангельскими глазами изменившей жены; он стих, замер и просветлел, поглаживая серебристыми языками желтый песок, как рассудительная, степенная кошка, совершающая утренний mуалет котят (Utw. 1, 441) / Cieśnina przypominała niewinne, anielskie oczy wiarołomnej żony, wody przycichty, uspokoity się i przejaśniały liżac srebrzystymi językami żótty piasek, jak roztropna stepowa kotka zajęta poranna toaleta swych kociat (SD, 155), Piekle odzyskanym: Om бельх камней в желтой пыли дороги лежали темно-синие тени, палый лист всех оттенков (Utw. 2, 403) / Od biatych kamieni na żótty pyt drogi kladty sie granatowe cienie, opadte liście wszystkich barw (PO, 9) i Poszukiwaczu przygód: Улиџы были обсажены пальмами; зонтичные вершины нх бросали на желтую от полудня землю синие тени (Utw. 2, 278) / Ulice wysadzane byly palmami. Ich parasolowate wierzchotki rzucaty niebieskawe cienie na pózótkta od upału ziemie (SzŻ, 229).

W dwóch utworach piasek został opisany przy pomocy barwy z pola czerwieni, która jest wyrażona przymiotnikiem красноватый derywowanym od nazwy podstawowej. Należą do nich opowiadanie Kolonia Lanfiеr: Лабиринт зеленых изгородей, полный сухой пьли, змеился по отлогому возвышению. Ноги Горна по шиколотку увязали в красноватом песке; пыль щекотала ноздри (Utw. 1, 294) / Labirynt zielonych przegród, peten suchego pytu, wit się na tagodnym wzniesieniu. Nogi Gorna po kostki grzęzty w czerwonawym piasku, pyt laskotal $w$ nozdrzach (Szcz., 18), Они вьили за изгородь, напутствуемьее оглушительным хрюканьем, и шли рядом, погружая ноги в горячий красноватый nесок (Utw. 1, 298) / Wyszli za ogrodzenie odprowadzani ogluszajacym chrumkaniem, szli obok siebie, pograżajac nogi w goracym czerwonym piasku (Szcz., 26) oraz Życie Gnora: Еще продолжалось неловкое и странное молчание, как вдруг случайно на искристом красноватом песке Гнор прочел фразу, выведенную дулом ружья или куском nалкu (Utw. 1, 624) / Jeszcze trwało niezręczne i dziwne milczenie, gdy 
nagle na iskrzacym sie czerwonawym piasku Gnor dojrzat przypadkowo słowa, nakreślone lufa strzelby lub kawałkiem kija (SD, 234).

Barwę współtworzącą pole czerwieni, wyrażoną rzeczownikiem nypnyp autor przywołuje $\mathrm{w}$ opisie skał oświetlonych promieniami zachodzącego słońca w Kolonii Lanfier: Лес редел, глубокие нросветы заканчивались пурпуром скал, блестящих в крови солнча, раненного Дианой (Utw. 1, 318) / Las był coraz rzadszy, głęokie prześwity kończyly sie purpura skat, blyszczacych w krwi stońca zranionego przez Diane (Szcz., 56).

\section{Konceptualizacja powietrza i zjawisk pogodowych}

Powietrze jest kolejnym elementem tworzącym świat przyrody nieożywionej. Do jego konceptualizacji A. Grin używa barw należących do pola czerni, bieli, szarości, błękitu i czerwieni.

Barwa czarna, wykorzystywana do opisu powietrza, w analizowanych utworach jest wyrażana przy pomocy przymiotnika черньий, tak jak w opowianiu Cieśnina Burz: Аян боролся с тревогой, однозвучный наплььв дум держал его в томительном напряжении, и сцены последних дней роились в черной стене воздуха, беглье, как обрывки сна (Utw. 1, 426) / Ayan walczył z lękiem, natłok jednostajnych myśli trzymat go w męczacym napięciu; ulotne jak strzępy snu sceny z ostatnich dni roity sie w czarnej ścianie powietrza (SD, 132) lub przy pomocy derywowanego od niego rzeczownika чернота w Kolonii Lanfier: И вместе с ним отлетел в бархатную черноту дух Огня, весельй, прыгающий $\partial у x$ пламени (Utw. 1, 292) / Razem z nim odleciat w aksamitna czerń duch ognia, wesoly, podskakujacy duch płomienia (Szcz., 15).

Jednokrotnie w językowej kreacji powietrza w tekstach opowiadań są poświadczone leksemy серый - w uworze Cieśnina Burz: B mom же момент личо его приняло выражение глубочайшего изумления: воздух стал тускльм, серым, небо залилось кровью, и жуткий немой мрак nomonuл все (Utw. 1, 412) / W tejże chwili twarz jego przybrata wyraz najgłębszego zdumienia; powietrze zamgliło sie, zszarzało, niebo zalało sie krwia $i$ niesamowity niemy mrok pochtonat wszystko (SD, 11) і голубой w Fandango: B открытое окно площадки сиял летний голубой воздух. Внизу лежал очень знакомьий двор - двор дома, в котором я жил (Utw. 3, 546) / Przez otwarte okno na podeście wpadt błękitny blask letniego powietrza (Sż், 359).

W opisach obłoków, z kolei, została przywołana tonacja biała, która różnicuje ich odcień dzięki wykorzystaniu przymiotnika бельй, серебристьий 
i czasownika серебрumь. Pierwszy z leksemów został wykorzystany w opowiadaniu Renе́e: Поезд шел полями с осевшим на ложбинах утренним чистым туманом. Пунчовые и белье облака, сторонясь, пропускали низкий пук ярких лучей, западавших на возвышения (Utw. 3, 86) / Pociag szedt polami z zalegajaca $w$ parowach poranna czysta mgła. Purpurowe $i$ białe obłoki rozchodzac się przepuszczały niski pęk ostrych promieni, które padały ze wzgórza (ON, 342). Obłoki o metalicznym połysku, natomiast, występują w dwóch utworach: Poszukiwacz przygód: B восемь часов вечера Аммон стоял перед тихим домом в саду, где ярко, пьшно и радостно молились иветь засыпающему в серебристых облаках солниу (Utw. 2, 295) / O ósmej wieczorem Ammon stanąt przed domem w ogrodzie, gdzie bujne jaskrawe kwiaty radośnie modlity się do zasypiajacego w srebrzystych obłokach słońca (SzŻ, 260) oraz Napowietrzne rusałki: Небо светлело; легкие и чистые облака серебрили розовеюший горизонт (Utw. 3, 293) / Niebo jaśniało, lekkie i czyste obłoki srebrzyty różowiacy się horyzont (Szcz., 247).

Z kolei w opowiadaniu Renée obraz obłoków został wykreowany przez autora z użyciem leksemu пунцовый, który odzwierciedla wpływ promieni wschodzącego słońca: Поезд шел полями с осевшим на ложбинах утренним иистым туманом. Пунцовье и белье облака, сторонясь, пропускали низкий пук ярких лучей, западавших на возвышения (Utw. 3, 86) / Pociag szedt polami z zalegajaca w parowach poranna czysta mgła. Purpurowe $i$ białe obłoki rozchodzac się przepuszczaty niski pęk ostrych promieni, które padały ze wzgórza (ON, 342).

Kolor biały pojawia się także w opisie oparów powietrza w utworze Mrok: Я заглянул в пропасть: на глубине - высоте колокольни - стоял непроничаемыи слой белого пара, скрывавшего бездну (Utw. 3, 47) / Zajrzałem w przepaść: w głębi, równej wielkości dzwonnicy, snuta się nieprzenikniona warstwa biatych oparów przykrywajacych dno otchtani (Szcz., 150), Тогда из глубины пропасти, из слоя белого холодного пара, опущенного в ее расселистьй зев, достигло моих ушей слабое ответное ржание, и я узнал голос лошади Рифта (Utw. 3, 49) / Wówczas z otchtani przepaści, z warstwy biatych, zimnych oparów, wiszacych w jej przestronnej paszczy, doleciała do moich uszu odpowiedź - słabe rżenie - rozpoznatem konia Ryfta (Szcz., 153).

Jedynym opadem atmosferycznym, który został przedstawiony w analizowanych utworach jest śnieg. Najczęściej stosowaną barwą do jego opisu jest biel, wskazująca na naturalny kolor tego zjawiska. Autor wykorzystuje zarówno nazwy przymiotnikowe, jak i imiesłowowe i rzeczownikowe. Przymiotnik бельй występuje w Piekłe odzyskanym: За окном лежит бельй 
снег (Utw. 2, 408) / Za oknem leży biaty śnieg (PO, 16), По снегу проила дама, молодая и красиво одетая, оставив на белизне снега маленькие частье следы, вытянутье по прямой линии (Utw. 2, 408) / Po śniegu przeszła jakaś pani, młoda i pięknie ubrana, pozostawiając na jego bieli mate $i$ czyste, wyciagnięte $w$ linię prosta ślady (PO, 16), w opowiadaniu Poszukiwacz przygód: Синий и бельй снег гор, зубчатый взлет которых тянулся полукругом вокруг холмистой равнины, Аммон увидел из окна поезда рано утром. Вдали солнечной полоской блестело море (Utw. 2, 277) / Wczesnym rankiem Ammon zobaczyt z okna pociagu błękitno-białe, ośnieżone szczyty gór, zębata korona otaczajace pótkolem pagórkowata równine (SzŻ, 228), Голубъе каскады взбивали снежную пену, прыгая со всех сторон с уступа на уступ, скрещиваясь и толкая друг друга, подобно вспугнутому стаду овеи, когда, попав в тесное место, струятся они живою волной бельх спин (Utw. 2, 296) / Btękitne kaskady wzbijaly śnieżna piane skaczac ze wszystkich stron po skalnych wystepach, wpadajac na siebie $i$ popychajac sie jak stado przestraszonych owiec, gdy tłoczy sie w ciasnym miejscu, kołyszac żywa fala biatych grzbietów (SzŻ, 262), oraz w tekście Szczurołap: Холод и мокрый снег, валивший над головами толпь вдали тучами бельх искр, придавали зрелищу отвратительный вид (Utw. 3, 321) / Zimno i mokry śnieg, miotajacy nad głowami ttumu ktęby biatych iskier, stwarzaty odpychajaca scenerie (Szcz., 251).

W utworze Piekło odzyskane został przywołany również imiesłów przymiotnikowy белевший: Столик, уставленный лекарствали, открыл мне, что я был тяжко и, может быть, долго болен. «Да, долго», подтвердил снег, белевший сквозь черноту стекла, в тишине ночной улиџь (Utw. 2, 404) / Zastawiony lekarstwami stolik wyjawit mi, że byłem ciężko $i$, być może, od dawna chory. „Tak, od dawna” - potwierdzit śnieg bielejący przez czerność szyby w ciszy nocnej (PO, 11) oraz rzeczownik белизна: Херам - очень небольшой город, и я быстро обошел его весь, по круговой уличе, наслаждаясь белизной снега и тишиной (Utw. 2, 406) / Cheram jest niewielkim miastem i szybko je obszedtem okólna ulica, rozkoszujac się cisza i biela śniegu (PO, 14).

W tym opowiadaniu pojawia się także leksem мертвенно-белье, który wskazuje na „brudny” odcień topniejącego śniegu: Зима умерла. Весна столкнула ее голой, розовой и дерзкой ногой в сырые овраги, где, лежа ничком в виде мертвенно-белых обтаявших пластов снега, старуха дышала еще в последней агонии холодным паром, но слабо u безнадежно (Utw. 2, 419) / Zima umarla. Wiosna naga, różowa $i z u-$ chwała stopa zepchnęta ja w wilgotne wawozy, gdzie leżac plackiem w po- 
staci martwobiałych, na wpót stajałych płatów śniegu, staruszka w agonii oddychała jeszcze zimna para, lecz słabo i beznadziejnie (PO, 31).

Obraz śniegu współtworzy barwa niebieska. Śnieg o tym zabarwieniu występuje tylko w utworze Poszukiwacz przygód, gdzie autor wykorzystuje do jego opisu leksem синий: Синий и бельй снег гор, зубчатый взлет которых тянулся полукругом вокруг холмистой равнины, Аммон увидел из окна поезда рано утром (Utw. 2, 277) / Wczesnym rankiem Ammon zobaczył z okna pociagu btękitno-białe, ośnieżone szczyty gór, zębata korona otaczajace pótkolem pagórkowata równine (SzŻ, 228) oraz przymiotnik голубой: Снеговые ручьи неслись в пьшной зелени по сверкающим каменньм руслам, звенели и бились вокруг. Голубые каскадь взбивали снежную пену, прыгая со всех сторон с уступа на уступ (Utw. 2, 296) / Dokoła huczaly lodowate strumienie, pędzac po błyszczacych kamieniach wśród zielonych brzegów. Błękitne kaskady wzbijały śnieżna piane skaczac ze wszystkich stron po skalnych wystepach (SzŻ, 262).

$\mathrm{W}$ opowiadaniu Walka ze śmiercia $\mathrm{w}$ językowej kreacji obrazu śniegu pojawia się barwa należąca do pola czerwieni - kolor różowy. Jest to nietypowa sytuacja, biorąc pod uwagę fakt, że opisywany jest krajobraz górski w ciaggu dnia: Отсюда, через пропасть, виден весь розовый снеговой ландиафт (Utw. 3, 128) / Stad widać za przepaścia cały zaśnieżony krajobraz (ON, 170).

Rzadko w analizowanych utworach pojawiają się opisy takiego zjawiska pogodowego, jakim jest mgła. W jej językowej kreacji obecna jest barwa biała i szara. Pole bieli jest reprezentowane przez rzeczownik белизна w opowiadaniu Fandango: Лунь не было видно, но светльй туман одевал небо, сообщая перспективе сонную белизну, переходящую в мрак (Utw. 3, 536) / Księżyca nie było widać, ale jasna mgła okrywała niebo zabarwiajac perspektywe senna biela, przechodzaca w mrok (SzŻ, 340) oraz przymiotnik серебристый w Cieśninie Burz: Cеребристый хлопок тумана колыхался у берегов, вода темнела, огненное крыло запада роняло ковры теней, земля стала задумчивой; птищы умолкли (Utw. 1, 425) / Srebrzysta bawetna mgly kotysała sie na brzegami, woda nabierała czerni, ogniste skrzydło zachodu rzucało kobierce cieni, ziemia pograżyła się $w$ zadumie, ptaki umilkty (SD, 131).

Jednokrotnie poświadczony w tekstach przymiotnik cuзыü, występujący w Cieśninie Burz, opisuje wieczorną mgłę na brzegu morza: Mope dblмилось, вечерний туман берега рвался в порыввах ветра, затягивая Пролив Бурь сизым флером (Utw. 1, 438) / Morze dymiło, wieczorna mgla nad brzegiem strzępiła się $w$ porywach wiatru, zasnuwajac Cieśnine Burz błękitnym woalem (SD, 150). 


\section{Podsumowanie}

W swoich opowiadaniach Aleksander Grin do kreowania obrazów przyrody nieożywionej używa licznych nazw barw, które reprezentują cztery pola barw chromatycznych: pole błękitu, zieleni, czerwieni i żółcieni oraz trzy pola barw achromatycznych: pole bieli, czerni i szarości. Użyte w analizowanych utworach wyrazy, odnoszące się do barw, reprezentują różne części mowy - nie tylko przymiotniki (15 leksemów), ale również rzeczowniki (6), przysłówki (1), czasowniki (2) i imiesłowy (2). Jak pokazują dane liczbowe, we wszystkich polach dominują przymiotniki, co niewątpliwie związane jest z główną funkcją nazw kolorów - określaniem cech desygnatów (Tabela 1.).

Tabela 1. Dane liczbowe i procentowe dotyczące poszczególnych pól barw

\begin{tabular}{|c|c|c|c|c|c|c|}
\hline \multicolumn{2}{|l|}{ Pole } & \multicolumn{3}{|c|}{ Liczba wystąpień } & \multicolumn{2}{|c|}{$\%$} \\
\hline \multirow[t]{4}{*}{ Barwy chromatyczne } & błękit & $\begin{array}{l}\text { голубой } \\
\text { синий } \\
\text { синева } \\
\text { лазурь }\end{array}$ & $\begin{array}{r}20 \\
8 \\
3 \\
1\end{array}$ & 32 & $\begin{array}{r}21,5 \\
8,6 \\
3,2 \\
1,1\end{array}$ & 34,4 \\
\hline & zieleń & $\begin{array}{l}\text { зеленый } \\
\text { зеленоватый } \\
\text { зеленеющий } \\
\text { зелень }\end{array}$ & $\begin{array}{l}3 \\
2 \\
1 \\
1\end{array}$ & 7 & $\begin{array}{l}3,2 \\
2,1 \\
1,1 \\
1,1\end{array}$ & 7,5 \\
\hline & czerwień & $\begin{array}{l}\text { красноватый } \\
\text { пурпур } \\
\text { пунцовый } \\
\text { розовый }\end{array}$ & $\begin{array}{l}3 \\
1 \\
1 \\
1\end{array}$ & 6 & $\begin{array}{l}3,2 \\
1,1 \\
1,1 \\
1,1\end{array}$ & 6,5 \\
\hline & żółcień & $\begin{array}{l}\text { желтый } \\
\text { желтеть }\end{array}$ & $\begin{array}{l}4 \\
1\end{array}$ & 5 & $\begin{array}{l}4,2 \\
1,1\end{array}$ & 5,3 \\
\hline \multirow[t]{3}{*}{ Barwy achromatyczne } & biel & $\begin{array}{l}\text { белый } \\
\text { белизна } \\
\text { серебрыстый } \\
\text { белевший } \\
\text { серебрить } \\
\text { мертвенно-белый }\end{array}$ & $\begin{array}{r}16 \\
4 \\
4 \\
1 \\
1 \\
1 \\
\end{array}$ & 27 & $\begin{array}{r}17,3 \\
4,3 \\
4,3 \\
1,1 \\
1,1 \\
1,1 \\
\end{array}$ & 29,2 \\
\hline & czerń & $\begin{array}{l}\text { черный } \\
\text { чернота } \\
\text { черно }\end{array}$ & $\begin{array}{l}9 \\
1 \\
1 \\
\end{array}$ & 11 & $\begin{array}{l}9,6 \\
1,1 \\
1,1 \\
\end{array}$ & 11,8 \\
\hline & szarość & $\begin{array}{l}\text { серый } \\
\text { сизый } \\
\text { стальной }\end{array}$ & $\begin{array}{l}2 \\
2 \\
1\end{array}$ & 5 & $\begin{array}{l}2,1 \\
2,1 \\
1,1\end{array}$ & 5,3 \\
\hline \multicolumn{2}{|l|}{ Ogółem } & \multicolumn{3}{|l|}{93} & \multicolumn{2}{|c|}{100} \\
\hline
\end{tabular}


Pośród barw chromatycznych, pojawiających się w analizowanych utworach, największą frekwencję mają barwy z pola błękitu (32 użycia), które wiążą się głównie z polem „wody powierzchniowe”. W twórczości A. Grina morze i inne zbiorniki wodne odgrywają ważną rolę, tam toczy się akcja wielu utworów. Do ich opisu wykorzystywane są takie odcienie koloru niebieskiego, jak: голубой, синий і лазурный. Warto zwrócić uwage na fakt, że w polskim przekładzie opowiadań zarówno przymiotnik голубой i синий ${ }^{9}$, w większości przykładów, jest zastąpiony leksemem błękitny ${ }^{10}$, wskazującym na intensywność barwy niebieskiej ${ }^{11}$, której prototypem jest kolor nieba bez określenia tonacji jego kolorystyki.

W nielicznych przykładach w tłumaczeniu analizowanych utworów pojawiają się inne nazwy barw odnoszaccych się do pola błękitu. Dwukrotnie w opowiadaniach Kapitan Duc (над синей водой / nad sinq woda) i Sprzedawca szczęścia (к синей узкой реке / nad sinq waska rzeka) do określenia koloru morza i rzeki przymiotnik синий został zastąpiony leksemem siny ${ }^{12}$, który określa barwę pośrednią między kolorem niebieskim i fioletowym, tak jak rosyjski wyraz. Jednokrotnie poświadczone są w tekstach przymiotniki, podkreślające odcień i nasycenie zabarwienia zbiorników wodnych - mo$d r y^{13}$, który zastępuje leksem синий w opowiadaniu Sprzedawca szczęścia (река развертывалась перед ним пышной, синей аллеей / przеd піт rozpościerała się milczaca rzeka, niczym przepyszna modra aleja) oraz granatowy ${ }^{14}$ - w Piekle odzyskanym (вечерние тени на воде синих озер / cienie wieczoru w wodzie granatowych jezior).

W opowiadaniu Cieśnina Burz, z kolei, w kształtowaniu obrazu morza uczestniczy rzeczownik лазурь ${ }^{15}$ (jasny odcień niebieskiego), zastąpiony

8 Голубой 'имеющих окраску одного из основных цветов спектра - среднего между зеленым и синим; цвета ясного неба; светло-синий' [Кузнецов 2000, 216].

9 Синий 'имеющих окраску одного из основных цветов спектра - среднего между голубым и фиолетовым' [Кузнецов 2000, 1186].

10 Błękitny 'intensywnie niebieski' [https://sjp.pwn.pl/szukaj/B\%C5\%82\%C4\%99kitny. html] (20.01.2020).

11 Niebieski 'mający barwę pogodnego nieba' [https://sjp.pwn.pl/szukaj/Niebieski\%20. html] (20.01.2020).

12 Siny 'niebieskofioletowy, czasem z szarym odcieniem' [https://sjp.pwn.pl/szukaj/Siny \%20.html] (20.01.2020).

13 Modry 'intensywnie niebieski' [https://sjp.pwn.pl/szukaj/Modry\%20.html] (20.01.2020).

14 Granat 'kolor ciemnoniebieski' [https://sjp.pwn.pl/szukaj/Granat\%20.html] (20.01.2020).

15 Лазурь 'светло-синий, лазурный цвет'; лазурный 'светло-синий, цвета ясного неба; небесно-голубой' [Кузнецов 2000, 485]. 
leksemem btękit ${ }^{16}$, który w żaden sposób nie określa intensywności koloru niebieskiego (корабль стройно чернел в лазури / statek czerniał wyniośle na tle btękitu).

Najczęściej wykorzystywaną w analizowanych utworach barwą achromatyczną jest reprezentowana przez 6 leksemów biel - 27 wystąpień, wśród których dominuje nazwa podstawowa i jej derywowaty.

Jak można zauważyć, barwami z pozostałych pól w opisach przyrody nieożywionej autor posługuje się w o wiele mniejszym stopniu (patrz. Tabela 1.). Warto jednak zwrócić uwagę na kreację obłoków w utworze $R e-$ nee, gdzie do ich opisu użył wyrazu nунцовыи ü17, określającego jasny odcień czerwieni, w przekładzie są one ciemnoczerwone - purpurowe ${ }^{18}$ (пунцовье и белье облака / purpurowe i biate oboki).

Obiekty przyrody nieożywionej opisywane w analizowanych otworach można podzielić na trzy klasy: wody powierzchniowe, powierzchnia terenu i podłoże skalne oraz powietrze i zjawiska pogodowe (Tabela 2.).

Tabela 2. Klasy obiektów opisywanych przez nazwy barw

\begin{tabular}{|c|c|c|c|c|c|c|c|c|}
\hline & 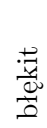 & 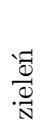 & 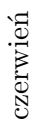 & 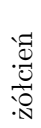 & $\overline{\mathbb{g}}$ & 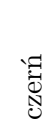 & 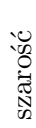 & 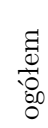 \\
\hline Wody powierzchniowe: & 28 & 6 & - & - & 5 & 7 & 1 & 47 \\
\hline morze & 7 & 4 & - & - & 2 & 5 & - & 18 \\
\hline rzeka & 13 & 1 & - & - & - & 1 & - & 15 \\
\hline jezioro & $\overline{4}$ & $\overline{-}$ & $\overline{-}$ & $\overline{-}$ & - & - & 1 & 5 \\
\hline ocean & 3 & 1 & - & - & 2 & 1 & - & 7 \\
\hline potok & 1 & - & - & - & 1 & - & - & 1 \\
\hline Powierzchnia terenu i podłoże skalne: & 1 & 1 & 4 & 5 & 7 & 2 & 2 & 22 \\
\hline ziemia & - & - & - & - & - & - & 1 & 1 \\
\hline wzniesienia & 1 & - & - & $\begin{array}{c}- \\
\end{array}$ & 1 & - & 1 & 3 \\
\hline równina & - & - & - & - & 1 & 1 & - & 2 \\
\hline brzeg & - & - & - & - & - & 1 & - & 1 \\
\hline skały i minerały & - & 1 & 4 & 5 & 5 & - & - & 15 \\
\hline Powietrze i zjawiska pogodowe: & 3 & - & 2 & - & 15 & 2 & 2 & 24 \\
\hline powietrze & 1 & - & - & - & - & 2 & 1 & 4 \\
\hline obłoki & - & - & 1 & - & 3 & - & - & 4 \\
\hline opary powietrza & - & - & - & - & 2 & - & - & 2 \\
\hline mgła & - & - & - & - & 2 & - & 1 & 3 \\
\hline \multirow[t]{2}{*}{ śnieg } & 2 & - & 1 & - & 8 & - & - & 11 \\
\hline & 32 & 7 & 6 & 5 & 27 & 11 & 5 & 93 \\
\hline
\end{tabular}

16 Błękit 'niebieska barwa' [https://sjp.pwn.pl/szukaj/B\%C5\%82\%C4\%99kit\%20.html] (20.01.2020).

17 Пунцовый 'ярко-красный; багровый' [Кузнецов 2000, 1046].

18 Purpurowy 'ciemnoczerwony z odcieniem fioletowym' [https://sjp.pwn.pl/szukaj/ Purpurowy\%20.html] (20.01.2020). 
Połowy nazw barw (47) użyto do kształtowania obrazu zbiorników wodnych - najwięcej z nich dotyczy morza (18) i rzeki (15). Jest to najobszerniejsze pole semantyczne związane z tonacją niebieską. W opisach pozostałych dwóch zbiorów obiektów kolor zostaje przywołany odpowiednio 22 i 24 razy. W obrazach powietrza i zjawisk pogodowych dominują barwy achromatyczne, w szczególności biel (15 użyć), a najczęściej opisywanym zjawiskiem jest śnieg. Biel jest również najczęściej przywoływanym kolorem w obrazach powierzchni i podłoża skalnego (7 użyć). Nazwy barw z pola błękitu i bieli stanowią ponad połowę (63\%) wszystkich wykorzystanych przez Grina do opisu kolorów przyrody nieożywionej leksemów.

\section{Źródła}

Грин А.С., 1994, Собрание сочинений в пяти томах, Москва. (Utw.)

Grin A., 1959, Piekło odzyskane, Wstępem opatrzył S. Pollak, Warszawa. (PO)

Grin A., 1960, Serce dżungli, (przełożyła I. Piotrowska), Warszawa. (SD)

Grin A., 1986, Szkartatne żagle. Opowiadania fantastyczne, przełożyli A. Bogdański, I. Piotrowska, S. Pollak, E. Rojewska-Olejarczuk, J. Szymak-Reiferowa, Warszawa. (Szż)

Grin A., 1971, Opowiadania niesamowite, Warszawa. (ON)

Grin A., 1987, Szczurołap i inne opowiadania, (wyboru dokonał J. Litwinow), Warszawa. (Szcz)

\section{Literatura}

Ampel-Rudolf M., 1994, Kolory. Z badań leksykalnych i składniowo-semantycznych języka polskiego, Rzeszów.

Inny słownik języka polskiego, 2000, pod red. M. Bańki, t. 1, Warszawa.

Narloch A., 2013, Цветообозначения в русском и польском языках. Структурно-семантический, терминологический и когнити-ный аспекты, Роznań.

Stownik języka polskiego PWN, [online], https://sjp.pwn.pl, [20.01.2020]

Stanulewicz D., 2014, Nieopisany błękit wody, która ściaga na siebie barwe nieba". Nazwy barw w powieści „Zatoka śpiewajacych traw” Stanisławy Fleszarowej-Muskat, „Studia Językoznawcze. Synchroniczne i diachroniczne aspekty badań polszczyzny" 13, s. 245-273.

Wielki słownik języka polskiego, pod red. P. Żmigrodzkiego, [online], https://wsjp.pl, [20.01.2020]

Tokarski R., 2004, Semantyka barw we wspótczesnej polszczyźnie, Lublin. 
Kuznecov S.A., 2000, Bol'šoj tolkovyj slovar' russkogo âzyka, Sankt-Peterburg. [Кузнецов С.А., 2000, Большой толковый словарь русского языка, Санкт-Петербург.]

Mel'nikova L.A., 2009, A.S. Grin: slovo - obraz, Minsk. [Мельникова Л.А., 2009, А.С. Грин: слово - образ, Минск.]

Černenok I. G., 2008, Simvolika cveta v hudožestvennom diskurse (na materiale korotkoj prozy Vol'fganga Borherta), (v:) „Izvestiâ Kaliningradskogo gosudarstvennogo tehničeskogo universiteta”, № 13, s. 179-183. [Черненок И. Г., 2008, Символика ивета в художественном дискурсе (на материале короткой прозы Вольфганга Борхерта), (в:), ,Известия Калининградского государственного технического университета", № 13, с. 179-183.]

\title{
NAMES OF COLORS IN DESCRIPTIONS OF INANIMATE NATURE (ON ALEXANDER GRIN'S NOVELS)
}

\author{
A BSTRACT
}

Key words: Grin, writer's idiolect, semantics of colour, inanimate nature

The analysis of color names provides valuable information about the models of perception, association and interpretation models of the world presented in a literary work. The main porpuose of his paper is to reconstruct a fragment of the color picture of the world of the outstanding Russian writer Aleksander Grin. The subject of analysis are the names of colors used by the novel's author to describe inanimate nature objects, which can be divided into three classes: 1) surface water, 2) surface and rocky ground, 3) air and weather phenomena.

Aleksander Grin uses in his novels numerous color names to create pictures of inanimate nature, which represent four fields of chromatic colours: blue, green, red and yellow, and three fields of achromatic colors: white, black and grey. The words, referring to colours, used in the analysed works are represented by different parts of speech - not only adjectives (15 lexems), but also nouns (6), adverbs (1), verbs (2) and participles (2). 